\title{
Teaching English as a Foreign Language in China
}

Wang Keqiang

The purpose of this paper is to share with international colleagues the history and status of TEFL in China, as well as methods or approaches to teaching
English in Chinese middle schools, colleges and universities. Finally, the author discusses problems, solutions and overall objectives of TEFL in China today.

\section{HISTORY}

\section{Beginnings: Qing Dynasty}

TEFL has existed in China for approximately one hundred years and has been subject to the policies and politics of the times. TEFL in China actually began in the latter half of the 19th century with the "Westernization Movement" started by some Chinese officials in the Qing Dynasty. With this movement came the influence of Western culture, trade and commerce. Some astute Chinese officials saw the need to learn English as a foreign language. The situation required establishment of institutes for teaching English. The first such institute (called "Tongwenguan") was set up in 1862 and in 1901 became part of the Beijing Normal University. This institution was a comprehensive higher education facility which included TEFL in the curriculum. ${ }^{2}$

\section{The Two Stages Prior to Liberation}

For forty years prior to the founding of the People's Republic of China in 1949, TEFL developed in two stages. The first covered twenty-two years from 1902 to 1922 and is characterized as the "Japanese model" because at that time Japan had great influence in China. As a result, English teaching in China was modelled after English teaching in Japan, that is to say, great attention was paid to reading and translation and little or no attention to spoken English. As for teaching materials, they were mainly compiled by foreign missionaries and/or based on excerpts from textbooks used abroad. ${ }^{3}$

The second stage lasted from 1922 to 1949 . During this time the teaching model shifted from Japan to Britain and America owing to their greater influence in China at that time. TEFL in this stage began to emphasize listening and speaking as students at that time had more 
exposure to the English language as spoken by the British and the Americans. As a result, in some middle schools ${ }^{4}$ English was used to teach other subjects such as mathematics, physics and chemistry. During this time, Chinese scholars such as Lin Yutang and Lin Handa ${ }^{5}$ began to play an important role in TEFL. They compiled textbooks which were more suitable for use in the Chinese cultural and educational context.

\section{Modern History: The People's Republic of China}

After liberation in 1949 TEFL in China underwent four stages. The first of these stages, which was a great set-back in my opinion, lasted from 1949 to 1956.

The founding of the People's Republic of China in 1949 brought about changes in national educational policies. ${ }^{6}$ However, few changes were made in English teaching materials and methods. English was taught in the traditional way. During this period China's relationship with the United States was tense because of the Korean war while the Soviet Union was called "Big Brother." The political situation between China and America did not encourage new efforts to teach English, and a great set-back for TEFL occurred during 1953-1956 when the Chinese people were encouraged to learn Russian rather than English. English as a subject was deleted from the school curriculum. Many English teachers had to learn and subsequently teach Russian.

The second stage, which can be termed the "English Language Renaissance," occurred from 1957 to 1966, during which many more countries established diplomatic relations with China, which allowed China to enter into more international relationships and trade. On the other hand, China's relations with the Soviet Union became worse. Accordingly, China's role in international affairs necessitated a command of English. As a result TEFL was gradually re-introduced into the school curriculum in addition to Russian. Students could study either Russian or English at schools, colleges and universities.

The third stage was a disastrous one. With the advent of the Cultural Revolution $^{7}$ in 1966, foreign language learning was removed from the curriculum. During 1966-69 all universities and colleges were closed. After graduating from middle schools, students were sent to work in the countryside or factories. With President Nixon's visit to China in 1972, there was a revival of TEFL. However, textbooks were poor, filled with political jargon such as: "Never forget class struggle!" or "Young educated people must go to the countryside for re-education!" Further, the texts were not based on any up-to-date information about language learning or language teaching methods.

The fourth stage began in 1977 with the overthrow of the Gang of Four and the end of the Cultural Revolution. Since then TEFL has been 
developing vigorously. Owing to the change in the fundamental policies, English has never been so important as it is today. The government's "Four modernizations program" and "open-door policy" have made the Chinese people, of all ages and occupations, cognizant of the importance of learning English. Currently, the desire to learn English is at a fever-pitch throughout China. It is estimated that in China today there are fifty million people learning English. Among them forty million are students at various schools; ten million are adults from all walks of life. Some learn English by radio or TV; others take English correspondence courses; and still others attend special English language classes. Many people study English independently. An English-speaking visitor to China may find himself surrounded by throngs of young people eager to practice their English. The government has initiated many effective measures which encourage all citizens to acquire proficiency in English, and TEFL is flourishing in China today.

\section{TEFL IN CHINESE SCHOOLS}

Since it is believed that a foreign language should be learned as early as possible so as to establish a solid foundation in that language, English is now considered one of the three major subjects in middle schools and in some primary schools. The Ministry of Education has clearly defined the aims, objectives, and linguistic criteria for each grade level. Five class hours per week have been allocated to English instruction and there is a nation-wide attempt to up-date teaching methodologies. English has become a major part of matriculation exams and counts heavily in entrance exams for college and university students. English as a foreign language is a compulsory course in colleges and universities. Without passing the English exam, students cannot obtain their graduate diplomas or become post-graduate students. After graduation, English is required for promotion in many work areas.

China has started to use the media as an effective reinforcer of English language development. Television programs such as "English on Sunday" and graded language materials (tapes and films) are widely used resources. In addition, China Daily, the national English newspaper, offers a good chance not only for foreigners to know about China, but also for students of English to improve their language proficiency. Moreover, it is estimated that there are over one hundred different journals and locally produced newspapers for English teaching and learning in China. For example, Learning English is a small middle school TEFL paper of which I am the editor-in-chief. This paper, established in Linfen, Shanxi Province, was first published in the summer of 1983 and now has a readership of one million students. ${ }^{8}$ 


\section{THE OPEN-DOOR POLICY: NEW DIRECTIONS, NEW PROBLEMS}

\section{Exchange Programs}

Since China first initiated its open-door policy, the door has continued to open wider and wider. More tourists and businessmen are visiting China while more and more Chinese are going abroad to study and work. This situation has caused a great change in approaches to TEFL in China. The previous emphasis on grammar and translation has been replaced with a renewed emphasis on communicative English skills in listening, speaking, reading and writing. All of these things have brought about new policies. Encouraged by the government, many colleges and universities now have exchange programs between English speaking countries and China. As a result, a large number of foreign experts and teachers ${ }^{9}$ from English-speaking countries have been invited to teach in China. At the same time, Chinese teachers of English are also being sent abroad to improve their language teaching skills. At Shanxi Teachers University, for example, there have been ten foreign experts since 1980 from both Canada and the United States.

\section{Training of TEFL Teachers}

The training of TEFL teachers occurs in foreign language departments of normal universities or colleges and foreign language institutes throughout the country. For example, the Foreign Language Department of Shanxi Teachers University, where I have been teaching EFL for more than ten years, is relatively young, having been in existence for only thirteen years. It has ten classes with 270 students. We have fifty native teachers, two Canadian experts and one American expert. In our department, we train senior middle school TEFL teachers. They learn all aspects of English-speaking, reading, writing and listening, in addition to social studies in the English language and classes in teaching methodology. They also have eight weeks of practice teaching in local middle schools, where they work with experienced EFL teachers. We have a TV lab and a sound lab where students can watch English TV programs or listen to English recordings. Our library has over seventy thousand books in the English language and approximately four hundred English language magazines and journals. These materials are well used by the student body. In addition to their studies, students of the Foreign Language Department have independently formed an English Language Club through which a wide variety of activities are conducted to encourage the active use of English.

After they have successfully completed four years of studies, Baccalaureate degrees are conferred upon the students, and the graduates are sent to teach EFL in various middle schools throughout the prov- 
ince. Several months before graduation, some students write the entrance examination for post-graduate studies. Those who pass this examination may study for three more years to obtain their Master's degrees.

As graduation approaches, the "Work assignment" is the key concern of each student as it determines his/her future. Many graduates wish to work in large cities where working and living conditions are better than in rural areas. However, the government encourages graduates to work in remote areas. In order to assist in the development of remote areas such as Tibet, the government has decided that those graduates who volunteer to teach in these areas will receive higher remuneration and can return to their hometowns after five to eight years of teaching. There are also a select few who endeavour to be accepted for study abroad.

\section{Problems}

There is not a sufficient number of qualified TEFL teachers in China today. Because of the importance of English to the "four modernizations," 10 every middle school and institution of higher learning wants to have ESL as one of its main courses. Therefore, the need for qualified TEFL teachers has become urgent. In Shanxi province, sixty percent of teachers now teaching EFL in middle schools are not fully qualified English teachers. Many of these teachers are middle school graduates, who have received no college language training. Some of them majored in Russian in college but now find themselves teaching English. Due to this lack of training, most teachers employ the "grammar-translation" method with their students, because they have not been trained to use any other methods.

As a result of this approach, many students have no practice in the aural/oral aspects of the language, and have poor communicative skills in English. Another unfortunate result of the use of such teaching methods is that gradually students begin to lose interest in studying English. The student's motivation is further dampened by the lack of opportunities to use their English and by the difficulties which arise from studying a language that is very different from their mother tongue. Moreover, middle school classes often have seventy or more students in one classroom. This makes it virtually impossible for an English teacher to meet the individual needs of the students.

Poorly edited teaching materials are yet another problem which confronts TEFL teachers in China. Many textbooks used in colleges were compiled in the early 1960s and their content is out-dated and not culturally and linguistically appropriate. The English spoken by some Chinese students to English speaking people seems to be the English of the 18 th or 19 th century. 
Lack of equipment is yet another problem which affects TEFL in China. For most rural students, the textbook is the sole source of English. Country schools cannot afford to purchase TV sets, cassette tape recorders, overhead projectors and slide projectors, to say nothing of language laboratories. Only a few key middle schools ${ }^{11}$ and institutions in the large cities have such equipment.

\section{Solutions}

Since the road to effective EFL teaching begins with well-trained teachers, the government has made an ambitious plan to train or retrain all TEFL teachers within five years. Some key language institutes and departments have been asked to run special training classes for middle school TEFL teachers. After two years of language study they will be qualified English teachers in senior middle schools. Other kinds of short-term training classes are also run at various levels for TEFL teachers. Furthermore, at each level of government, there is a section or an official in charge of TEFL. Their responsibilities include the organizing of professional exchanges among TEFL teachers and the development of the teachers' language and teaching proficiencies.

Since China's "open-door policy" encourages interaction with foreigners in a variety of contexts, the communicative skills of English should be considered a priority in our EFL teaching. Recentiy, there has been a nation-wide effort to implement more effective language teaching methods. However, other factors, such as China's population, the unavailability of supplies and equipment, and the diversity of the two languages/cultures involved, necessitate the development of approaches unique to the Chinese context. These approaches to TEFL must be incorporated into the strengths of the existing methods and materials to better meet the needs of China today.

In recent years many universities and colleges have tried to up-date their teaching materials by introducing comtemporary textbooks from abroad. But it is critical that texts be developed which are sensitive to the unique needs of Chinese students who are studying English. In compiling textbooks, it is essential to take notice of the different cultures of people who speak different languages. Neglecting the different cultures may cause communicative distress as when a Chinese student greets his foreign teacher with "Where are you going?" or "Have you had your lunch?"12

Our government is diligently trying to provide more teaching equipment for TEFL, first in key schools and then in other schools; however, the immensity of the country makes this an awesome task. Therefore, at the present, teachers need to develop materials which are not dependent upon the use of electronic equipment.

Since China realizes the importance of English as a communicative 
medium, English is not viewed as merely an academic undertaking. Rather, English is needed as the key to open doors to new worlds. Based on this insight, some universities and colleges have undergone some reforms in TEFL. For example, at the Beijing Foreign Languages Institute the students in the first two years study English in order to lay a solid linguistic foundation. In the last two years, they use English as a means to study other courses such as journalism, literature, linguistics and translation. Courses such as these can assist China in its everincreasing role in the world community.

\section{SUMMARY}

I have reviewed the history of TEFL in China, with particular emphasis on contemporary directions, problems and solutions. As I indicated earlier, the TEFL experience has had many ups and downs due to the vagaries of the various political systems which have emerged in the last eighty-five years in China. Since liberation in 1949, we have realized the need to make the English language as a foreign language "live" for our students. We have not always been successful, but we can already see progress as the result of our recent efforts.

Our current directions offer promise that our students may become more than proficient in English grammar-translation: our goal is to enable them to use both written and spoken English appropriately for particular cultural contexts. We are already seeing the fruits of new government policies in education. With more time and constant commitment to our goals, we will realize changes and improvements rapidly in China.

Confucius once said, "When three of us walk together, one of the others can be my teacher." This saying demonstrates that the Chinese people are traditionally open-minded and receptive to learning from others. I believe that with the aid of teaching materials and other vital resources from our international colleagues, we will surely meet our goal.

\section{NOTES}

1. "Westernization Movement" is a set of policies aimed at imitating the technology of the capitalist countries.

2. TEFL was first listed in the curriculum of 1902 according to "His Majesty's Teaching Standards for Primary and Secondary Institutions" of the Qing Dynasty.

3. These include Nesfield English Grammar by J.C. Nesfield published in 1899 and other English textbooks by E.A. Spencer, H.B. Graybill and others.

4. These middle schools were usually run by foreign missionaries.

5. Lin Yutang, an English professor at Peking University in the 1920s, who wrote 
Kaiming English Grammar. Lin Handa was also an English professor at Peking University.

6. Changes in national policies included education for the workers, peasants and soldiers of China and imitation of the Soviet Union's cultural and educational policies.

7. The Cultural Revolution, a great disaster for the Chinese people, took place from 1966 to 1976. This revolution was initiated by Mao Zedong and taken advantage of by the "Gang of Four" (Jiang Qing, Zhang Chunqiao, Yao Wenyuan and Wang Hongwen).

8. Learning English, a small-sized bilingual paper for middle school students learning English, was first run by a country middle school English teacher at his own expense. Through many twists and turns it has gained popularity among middle school students throughout the country.

9. For example, in 1980 there were only forty or fifty American experts teaching in China. Now there are over eight hundred experts.

10. "Four Modernizations" refers to the modernization of industry, agriculture, national defence and science and technology. These four goals are now crucial to China's national policies.

11. In China, there are a number of "key" middle schools in each province. For example, Shanxi Province has more than thirty provincial key middle schools, for which modern teaching facilities are provided by the provincial government. Key middle schools are generally granted more funding than others and have more comprehensive academic goals.

12. It is culturally appropriate in China to greet with "Have you eaten?" "Where have you been?"

\section{REFERENCES}

Tang Jun. (1982). English language teaching material of middle schools in the past thirty-two years. Curriculum, Teaching Material and Method, 1, 40-45.

Tang Jun. (1982). Middle School English language teaching in 1902-1949. Curriculum, Teaching Material and Method, 1, 46-50.

Li Tingxiang. (1983). English methodology. Beijing: Higher Education Publishing House.

Tang Lixing. (1983). TEFL in China: Methods and techniques. Shanghai: Shanghai Foreign Language Education Press.

\section{THE AUTHOR}

Wang Keqiang graduated from the Beijing Foreign Languages Institute in 1961. He taught English to rural high school students in Shanxi Province, and since 1974, has taught EFL at Shanxi Teachers University. He has also been involved in the translation and development of professional material relating to TEFL for Chinese students. Now he is an associate professor and Director of the Reading and Writing Research Section of the Foreign Language Department. Concurrently, he is the editor-in-chief of Learning English. 